\title{
Upregulation of FNDC5 gene expression in C2C12 cells after single and combined treatments of resveratrol and ATRA
}

\author{
Elahe Abedi-Taleb ${ }^{1}$, Zahra Vahabii ${ }^{2,3}$, Ehsan Sekhavati-Moghadam ${ }^{4}$, Leila Khedmat ${ }^{5}$, Shima Jazayeri ${ }^{6}$ and \\ Ali Akbar Saboor-Yaraghi, ${ }^{1,7^{*}}$
}

\begin{abstract}
Background: Irisin is a newly discovered myokine that secreted from skeletal muscle cells. Several studies showed that irisin involves in thermogenesis and increases the expression of browning markers such as uncoupling protein1 that in turns induces the conversion of white adipose tissue to brown fat. Resveratrol (Res) and all-trans retinoic acid (ATRA) can also upregulate the expression of thermogenesis genes. In the present study, the effects of single and combined treatments of Res and ATRA on fibronectin type III domain containing 5 (FNDC5) gene expression was explored.
\end{abstract}

Methods: The mouse myoblasts, C2C12 cells, were seeded in 6-well plastic plates and cultured in DMEM media. After differentiation, in a pilot study, C2C12 myotubes were treated with different concentrations of Res and ATRA for $12 \mathrm{~h}$. The best result was obtained by treatment of 1 and $25 \mu \mathrm{M}$ of Res and $1 \mu \mathrm{M}$ of ATRA. Then the main study was continued by single and combined treatment of these compounds at chosen concentration. After treatments, total RNA was extracted from C2C12 cells. Complementary DNA (CDNA) was generated by the CDNA synthesis kit and FNDC5 mRNA expression was evaluated by the real-time PCR method.

Results: The FNDC5 gene expression in C2C12 myotubes of alone-treated with $1 \mu \mathrm{M}, 25 \mu \mathrm{M}$ Res and $10 \mu \mathrm{M}$ ATRA did not change compared to vehicle group. However, in combination-treated the expression of FNDC5 gene was significantly increased compared to vehicle group.

Conclusion: This is the first evidence that Res and ATRA can regulate FNDC5 gene expression in C2C12 myotubes. More investigations are necessary to explore the therapeutic effects of these nutrients in obesity, diabetes, cardiac and neurovascular disease.

Keywords: FNDC5, Thermogenesis, Retinoic acid, Resveratrol

\section{Background}

The skeletal muscle is an endocrine organ and is able to generate and release some active proteins called myokines [1]. It has been shown that irisin, a newly discovered myokine, secretes into the circulation after cleavage from the fibronectin type III domain containing-5 (FNDC5 (gene and numerous researchers highlighted the muscle intervention in metabolism [2-5].

\footnotetext{
* Correspondence: asaboor@tums.ac.ir

'Department of Cellular and Molecular Nutrition, School of Nutritional Sciences and Dietetics, Tehran University of Medical Sciences, Tehran, Iran ${ }^{7}$ Department of Immunology, School of Public Health, Tehran University of Medical Sciences, Tehran 141613151, Iran

Full list of author information is available at the end of the article
}

Irisin/FNDC5 identified as a cytokine which imitates the beneficial effect of exercise on adipose tissue [6]. FNDC5 is stimulated by peroxisome proliferator-activated receptor $\gamma$ coactivator- $1 \alpha$ (PGC- $1 \alpha)$ and expressed in adipocyte and many tissues such as kidney, liver, heart, and lung [7] but the expression of FNDC5 in muscle tissue is 200 fold greater than in adipose tissue [8]. Irisin is a potentially candidate marker for heart and neurovascular disease [9-11]. PGC-1 $\alpha$ identified as a regulator of mitochondrial function. In addition, this component coactivates peroxisome proliferator-activated receptor (PPAR) $\alpha$ and PPAR $\gamma$. There is an enriched expression of PGC-1 $\alpha$ in brown adipose and other thermogenesis tissues. Cold exposure and fasting induce this master regulator in

(c) The Author(s). 2019 Open Access This article is distributed under the terms of the Creative Commons Attribution 4.0 International License (http://creativecommons.org/licenses/by/4.0/), which permits unrestricted use, distribution, and 
human metabolism. Activation of uncoupling protein-1 (UCP-1), is mediated by PGC- $1 \alpha$ through FNDC5 which induces thermogenic program, the biological conversion of white adipocyte (WAT) into brite/beige adipocyte (BAT) [12, 13]. The thermogenic program is an attractive target in the treatment of obesity. BAT plays an important role in regulation of body weight through increasing the energy expenditure [14]. Obese people may have various diseases including type 2 diabetes, heart disease and cancer [15]. Obesity is a serious health problem and linked to genetic predisposition and sedentary lifestyle [16]. Although the considerable focus has been put on the understanding the etiology of obesity and diabetes, the role of several factors from skeletal muscle is unknown [17]. A recent study investigated the signal generated by peripheral tissues including fat and skeletal muscle [1]. A very recently published study showed that FNDC5 expression is induced by ATRA treatment [18]. Several studies are investigated in irisin different functions. Nevertheless, the potential role of irisin in humans is unclear and there are still many questions in the exact role of irisin in metabolism.

ATRA is an active derivative of vitamin A and Res is a type of natural phenol which can be found in some foods including the skin of grapes, blueberries, raspberries, and mulberries $[19,20]$. Recent studies revealed the signaling pathway of Res and ATRA effects on PGC$1 \alpha$ activity [21-29]. It has been shown that ATRA and Res regulate thermogenesis by inducing the expression of UCP-1 [30-32].

The present research investigated the effects of single and combined treatments of Res and ATRA on the FNDC5/ irisin gene expression in $\mathrm{C} 2 \mathrm{C} 12$ cells.

\section{Materials and methods}

\section{Cell culture}

C2C12 mouse myoblasts were purchases from a cell bank (Pasteur Institute, Tehran, Iran) and cultured in DMEM (Gibco, Invitrogen, UK) containing $1000 \mathrm{mg} / \mathrm{L}$

Table 1 Mean values of FNDC5 gene expression fold change in pilot study after 3- and 12-h incubation

\begin{tabular}{|c|c|c|c|c|}
\hline \multirow[t]{2}{*}{ Groups } & \multicolumn{2}{|c|}{$3 \mathrm{~h}$ incubation } & \multicolumn{2}{|c|}{$12 \mathrm{~h}$ incubation } \\
\hline & $\overline{\text { Value }^{a}}$ & $P$ value $^{b}$ & $\overline{\text { Value }^{a}}$ & $P$ value ${ }^{b}$ \\
\hline ATRA $(0.1 \mu \mathrm{M})$ & $0.50 \pm 0.52$ & $>0.9$ & $4.79 \pm 4.86$ & 0.9 \\
\hline ATRA $(1.0 \mu \mathrm{M})$ & $0.92 \pm 0.45$ & $>0.9$ & $16.09 \pm 6.01$ & 0.9 \\
\hline ATRA $(10 \mu \mathrm{M})$ & $3.90 \pm 2.07$ & 0.6 & $15.24 \pm 21.39$ & 0.4 \\
\hline $\operatorname{Res}(0.1 \mu \mathrm{M})$ & $2.72 \pm 2.16$ & 0.9 & $15.68 \pm 4.41$ & 0.4 \\
\hline $\operatorname{Res}(1.0 \mu \mathrm{M})$ & $4.15 \pm 2.27$ & 0.5 & $8.77 \pm 5.60$ & 0.4 \\
\hline $\operatorname{Res}(25 \mu \mathrm{M})$ & $1.33 \pm 0.82$ & $>0.9$ & $11.90 \pm 6.30$ & 0.9 \\
\hline $\operatorname{Res}(50 \mu \mathrm{M})$ & $4.15 \pm 4.35$ & 0.5 & $4.80 \pm 3.87$ & 0.7 \\
\hline Vehicle & $1.05 \pm 0.45$ & - & $1.03 \pm 0.32$ & - \\
\hline
\end{tabular}

${ }^{\mathrm{a}}$ Data were represented as mean \pm SD $(n=2)$

${ }^{b}$ Comparing each group with the vehicle group (The mean difference is significant at the 0.05 level)
Table 2 Groups of main study using selected concentrations of Res and ATRA

\begin{tabular}{ll}
\hline Group 1 & Res $(25 \mu \mathrm{M})$ \\
\hline Group 2 & $\operatorname{Res}(1 \mu \mathrm{M})$ \\
Group 3 & ATRA $(10 \mu \mathrm{M})$ \\
Group 4 & $\operatorname{Res}(12.5 \mu \mathrm{M})+$ ATRA $(5 \mu \mathrm{M})$ \\
Group 5 & $\operatorname{Res}(0.5 \mu \mathrm{M})+$ ATRA $(5 \mu \mathrm{M})$ \\
Group 6 & $\operatorname{Res}(25 \mu \mathrm{M})+$ ATRA $(10 \mu \mathrm{M})$ \\
Group 7 & $\operatorname{Res}(1 \mu \mathrm{M})+$ ATRA $(10 \mu \mathrm{M})$ \\
Group 8 & Vehicle \\
\hline
\end{tabular}

glucose, supplemented with $10 \%$ heat-inactivated fetal bovine serum (Gibco, Invitrogen, UK) and $100 \mathrm{U} / \mathrm{ml}$ penicillin/streptomycin (Sigma, USA) at $37^{\circ} \mathrm{C}$ in $5 \%$ $\mathrm{CO}_{2}$ and $88 \%$ humidity. Cells viability was assessed by the trypan blue exclusion test.

To induce myogenic differentiation, cells were seeded at a concentration of 150,000 cells/well in 6-well plastic plates. After $48 \mathrm{~h}$, cells at $60-80 \%$ confluence were washed once with serum-free DMEM, and the media were shifted to differentiation medium (DMEM supplemented with $2 \%$ heat-inactivated horse serum). The media were changed every $24 \mathrm{~h}$ for 2,3 , or 6 days (Table 1).

Doses and incubation time in this study were obtained based on a pilot test. First, the effect of Res at concentrations $(50,25,1$ and $0.1 \mu \mathrm{M})$ and ATRA at concentrations $(10,1$ and $0.1 \mu \mathrm{M})$ at 3 and $12 \mathrm{~h}$ was investigated on gene expression of Fndc5 (Table 2).

\section{RNA extraction, CDNA synthesis, and real-time polymerase chain reaction}

After treatments, total RNA was extracted from $\mathrm{C} 2 \mathrm{C} 12$ cells using RNeasy Plus mini kit (Qiagen, Valencia, CA) according to the manufacturer's protocol. RNA samples were dissolved in DEPC-treated water. Their concentrations and qualifications determined by A260/A280 measurements using a spectrophotometer (NanoDrop Technologies, USA) and the values ranging from 1.9 to 2.1 were considered as acceptable. Synthesis of cDNA was performed using cDNA synthesis kit (Takara, Otsu, Japan) and used to FNDC5 mRNA expression by Real-time PCR (Applied Biosystem, Foster City, CA, USA) method. Real-time PCR was performed with SYBR Green (TaKaRa Ex Taq ${ }^{\circ}$ ) intercalating dye. Reactions were

Table 3 Sequencing and information about primers

\begin{tabular}{lllll}
\hline Gene Name & Sequence & Length & Tm & GC\% \\
\hline FNDC5(F) & ATGAAGGAGATGGGGAGGAA & 20 & 54.50 & 50.00 \\
FNDC5(R) & GCGGCAGAAGAGAGCTATAACA & 22 & 55.30 & 50.00 \\
GAPDH(F) & CACTGCCACCCAGAAGACTG & 20 & 55.20 & 60.00 \\
GAPDH(R) & CCAGTGAGCTTCCCGTTCAG & 20 & 56.80 & 60.00 \\
\hline
\end{tabular}




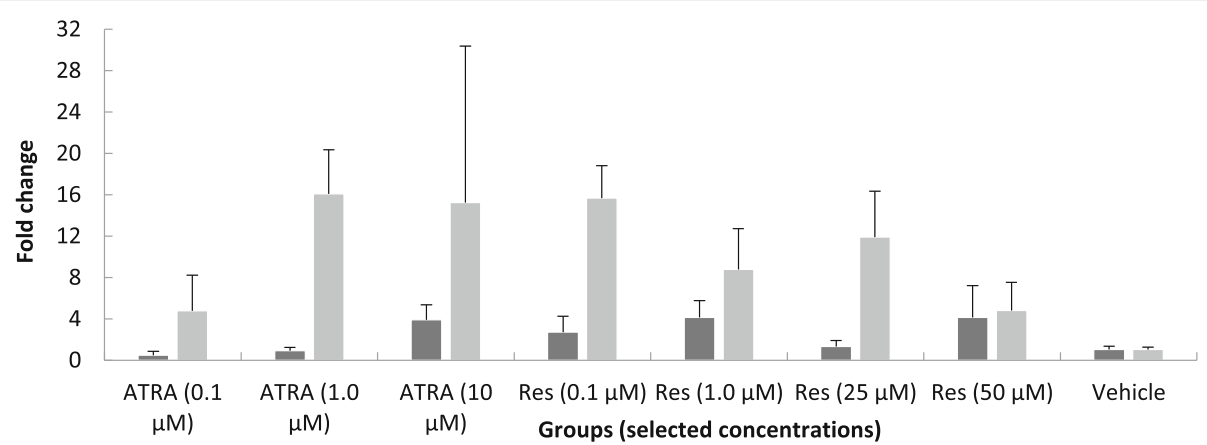

Fig. 1 The effects of different concentrations of ATRA and Res on the fold change of FNDC5 gene expression in C2C12 cells after 3 and $12 \mathrm{~h}$ incubation in the pilot study

run in 40 cycles and two-step protocol, melting: $15 \mathrm{~s}$ at $95^{\circ} \mathrm{C}$, annealing, and extension: $60 \mathrm{~s}$ at $60^{\circ} \mathrm{C}$. After completion of amplification cycles, the melt curve was generated to verify if a single gene product had been amplified. Primer pairs for target genes were designed using Primer Express 3 software (Applied Biosystems, Foster City, CA, USA) and purchased from Metabion. Primer sequences are presented in Table 3. Normalizations of the target gene expression were done using the glyceraldehyde 3-phosphate dehydrogenase (GAPDH) gene expression level.

\section{Statistical analysis}

Results represented at two independent experiments performed in duplicate. The calculation of the gene expression was based on the Paffl's method. Data represented with the analysis of variance (ANOVA) mean and standard error for numerical variables. The mean gene expression was compared with test followed by Dunn's post-hoc test. All statistical tests were two-sided and $P<$ 0.05 was considered to be statistically significant.

\section{Results}

\section{Gene expression of FNDC5 in pilot study after $3 \mathrm{~h}$ treatment by ATRA or res}

The expression of FNDC5 in C2C12 cells was evaluated. The real-time PCR analysis demonstrated that after $3 \mathrm{~h}$ treatment, neither ATRA nor Res could induce mRNA expression of FNDC5 gene. The difference between the effect of ATRA and Res treatments was not statistically significant (Table 1 and Fig. 1).

\section{Gene expression of FNDC5 in pilot study after $12 \mathrm{~h}$ treatment by ATRA or res}

There was no significant increase in levels of FNDC5 expression with ATRA or Res at $12 \mathrm{~h}$ in pilot study. FNDC5 expression was not changed in all treatment groups compared to control. (Table 1 and Fig. 1).

\section{Combination treatments of ATRA and res}

The effect of ATRA and its combination with Res and the synergistic and additive effects on FNDC5 expression in $\mathrm{C} 2 \mathrm{C} 12$ Cells were explored. When the $\mathrm{C} 2 \mathrm{C} 12$ was treated with half doses of Res and ATRA the expression of FNDC5 gene significantly elevated. The graph of each compound alone and in combination is shown in Fig. 1. These results are indicative of strong synergistic and additive effects with ATRA and Res (Tables 4, 5 and 6, Fig. 2).

Comparison of the results of single therapy with combination treatments, showed that in combination treatment with the half dose of each nutrient in the single therapy, had the best effect that indicating the synergistic effects of these two compounds (Tables 5 and 6).

\section{Discussion}

The results of this study showed that combined treatments of ATRA and Res increased the expression of FNDC5 in C2C12 cells compared to control groups. To our knowledge, the present study is the first to demonstrate the ability of co-treatment of Res and ATRA in upregulation of FNDC5 gene expression. The gene expression of FNDC5 in single treatments of various

Table 4 Mean and standard error of FNDC5 gene expression fold change in the main study (After $12 \mathrm{~h}$ incubation)

\begin{tabular}{llll}
\hline Groups & Mean & S.E & $P_{\text {value }}$ \\
\hline Res $(25 \mu \mathrm{M})$ & 1.01 & 0.21 & $P>9.0$ \\
Res $(1 \mu \mathrm{M})$ & 1.1 & 0.01 & $\mathrm{P}>9.0$ \\
ATRA $(10 \mu \mathrm{M})$ & 2.02 & 0.24 & 0.299 \\
$\operatorname{Res}(12.5 \mu \mathrm{M})+$ ATRA $(5 \mu \mathrm{M})$ & 2.72 & 0.31 & ${ }^{\mathrm{a}} 0.021$ \\
$\operatorname{Res}(0.5 \mu \mathrm{M})+$ ATRA $(5 \mu \mathrm{M})$ & 2.90 & 0.39 & ${ }^{\mathrm{a}} 0.009$ \\
$\operatorname{Res}(25 \mu \mathrm{M})+$ ATRA $(10 \mu \mathrm{M})$ & 3.20 & 0.61 & ${ }^{\mathrm{a}} 0.002$ \\
$\operatorname{Res}(1 \mu \mathrm{M})+$ ATRA $(10 \mu \mathrm{M})$ & 2.90 & 0.60 & ${ }^{\mathrm{a}} 0.010$ \\
Vehicle & 1.03 & 0.13 & - \\
\hline
\end{tabular}

${ }^{a}$ The mean difference is significant at the 0.05 levels

${ }^{\mathrm{b}}$ Comparing each group with the vehicle group. 
Table 5 Pairwise comparison the effect of single and half doses of Res and ATRA on FNDC5 expression in C2C12 by Turkey analysis

\begin{tabular}{|c|c|c|c|c|c|}
\hline & & \multirow{2}{*}{$\begin{array}{l}\text { Mean } \\
\text { Difference }\end{array}$} & \multicolumn{2}{|c|}{ 95\% Confidence Interval } & \multirow[t]{2}{*}{ Sig. } \\
\hline & & & Lower Bound & Upper Bound & \\
\hline \multirow[t]{2}{*}{ Res 25} & $\operatorname{Res}(12.5 \mu \mathrm{M})+\operatorname{ATRA}(5 \mu \mathrm{M})$ & $-1.64^{\mathrm{a}}$ & -2.74 & -.53 & $.003^{\circ}$ \\
\hline & $\operatorname{Res}(0.5 \mu \mathrm{M})+\operatorname{ATRA}(5 \mu \mathrm{M})$ & $-1.79^{\mathrm{a}}$ & -2.90 & -.68 & $.001^{c}$ \\
\hline \multirow[t]{2}{*}{ Res 1} & $\operatorname{Res}(12.5 \mu \mathrm{M})+\operatorname{ATRA}(5 \mu \mathrm{M})$ & $-1.52^{\mathrm{a}}$ & -2.62 & -.41 & $.005^{\circ}$ \\
\hline & $\operatorname{Res}(0.5 \mu \mathrm{M})+\operatorname{ATRA}(5 \mu \mathrm{M})$ & $-1.67^{\mathrm{a}}$ & -2.78 & -.56 & $.002^{2}$ \\
\hline \multirow[t]{2}{*}{ ATRA 10} & $\operatorname{Res}(12.5 \mu \mathrm{M})+\operatorname{ATRA}(5 \mu \mathrm{M})$ & -.63 & -1.74 & .47 & .426 \\
\hline & $\operatorname{Res}(0.5 \mu \mathrm{M})+$ ATRA $(5 \mu \mathrm{M})$ & -.78 & -1.89 & .31 & .232 \\
\hline
\end{tabular}

a The mean difference is significant at the 0.05 level

concentrations of ATRA and Res was also upregulated but these increases were not statistically significant.

One of the advantages of combination therapy is that fewer doses of each drug can be used, which can help to reduce the possible side effects of medications.

Res known as a natural polyphenol that has anti-obesity effect due to activation of UCP-1 [33]. There is evidence that shows Res in 1-10 $\mu \mathrm{M}$ can inhibit differentiation of adipogenic cells into preadipocytes [34]. Andrade, et al. observed that oral administration of Res in mouse promoted thermogenesis in adipose tissue by increasing UCP-1 [31]. Retinoic acid (RA) also has anti-obesity effect by counteracting adipogenesis and promoting energy expenditure. Several studies highlighted this role for RA and several mechanisms have been proposed [35-37] . Stimulation of adrenergic pathway is a main trigger for thermogenesis [38]. In a recent study ATRA can upregulate FNDC5 expression at the same dose level of our study $(10 \mu \mathrm{M})$ but in the longer duration $(24 \mathrm{~h})$ [18]. Res is an adrenergic receptor agonist that increases intracellular cyclic adenosine monophosphate (cAMP) levels [26]. Furthermore Res enhances cAMP by inhibiting phosphodiesterase4 (PDE4) [22]. cAMP increases the protein expression level of PGC- $1 \alpha$ by two ways. First is sirtuin 1 (SIRT1) that affect PGC-1 $\alpha$ activity through phosphorylation and acetylation $[23,24]$. The second way is related to protein kinase A (PKA) and cAMP response element binding protein (CREB). The cAMP signalling pathway activates CREB through PKA. Then, the transcription factor CREB activates the expression of PGC-1 $\alpha$ gene [21]. Therefore, Res is able to upregulate the expression of PGC- $1 \alpha[39,40]$. It has reported that ATRA can also increase the PGC-1 $\alpha$ expression through two pathways. First is Mitogen-activated protein kinase (MAPK)- Extracellular Signal-regulated Kinase-1 (ERK) - CREB and second is MAPK-p38-CREB activation [41]. An increase in expression of PGC-1 $\alpha$ can enhance the expression of FNDC5 [42]. In accordance with these evidences, the results of the present study for the first time showed that Res and ATRA in additive and synergistic manner could increase the expression of FNDC5 (irisin) gene.

Since the discovery of irisin which is able to induction of thermogenesis, a few studies investigated the correlation of this myokine and nutrients. The obtained results in previous studies showed undesirable fatty acid profile is leading to high plasma irisin in children, especially in obese children. This study suggested the role of irisin in protection against metabolic disturbance [43]. In a previous study, the effect of vitamin A on FNDC5 gene expression has been investigated and the results showed that vitamin A can increase gene expression of FNDC5 through the ERK1/2-CREB-PGC1 $\alpha$ FNDC5 pathway [44]. Another study observed no association between 28 days vitamin $\mathrm{D}$ supplementation in a single dose (100.000 IU) and level of plasma irisin. Indeed, vitamin D could not effect on plasma irisin in human adults [45]. Seo et al. found no effect of treatment with aged garlic extract on the production of irisin in mouse skeletal muscle cells in vitro [46].

The results of the present study were consistent with previous reports that showed vitamin A promoted irisin

Table 6 Pairwise comparison the effect of single and combined doses of Res and ATRA on FNDC5 expression in C2C12 by Turkey analysis

\begin{tabular}{|c|c|c|c|c|c|}
\hline & & \multirow{2}{*}{$\begin{array}{l}\text { Mean } \\
\text { Difference }\end{array}$} & \multicolumn{2}{|c|}{ 95\% Confidence Interval } & \multirow[t]{2}{*}{ Sig. } \\
\hline & & & Lower Bound & Upper Bound & \\
\hline \multirow[t]{2}{*}{ Res 25} & $\operatorname{Res}(25 \mu \mathrm{M})+$ ATRA $(10 \mu \mathrm{M})$ & $-2.08^{\mathrm{a}}$ & -3.8162 & -.3620 & $.015^{\mathrm{a}}$ \\
\hline & $\operatorname{Res}(1 \mu \mathrm{M})+\operatorname{ATRA}(10 \mu \mathrm{M})$ & $-1.77^{\mathrm{a}}$ & -3.5007 & -.0465 & $.043^{\mathrm{a}}$ \\
\hline \multirow[t]{2}{*}{ Res 1} & $\operatorname{Res}(25 \mu \mathrm{M})+$ ATRA $(10 \mu \mathrm{M})$ & $-1.96^{\mathrm{a}}$ & -3.6953 & -.2411 & $.022^{\mathrm{a}}$ \\
\hline & $\operatorname{Res}(1 \mu \mathrm{M})+\operatorname{ATRA}(10 \mu \mathrm{M})$ & -1.65 & -3.3798 & .0743 & .064 \\
\hline \multirow[t]{2}{*}{ ATRA 10} & $\operatorname{Res}(25 \mu \mathrm{M})+\operatorname{ATRA}(10 \mu \mathrm{M})$ & -1.08 & -2.8079 & .6462 & .343 \\
\hline & $\operatorname{Res}(1 \mu \mathrm{M})+\operatorname{ATRA}(10 \mu \mathrm{M})$ & -.76 & -2.4924 & .9617 & .655 \\
\hline
\end{tabular}

a The mean difference is significant at the 0.05 level 


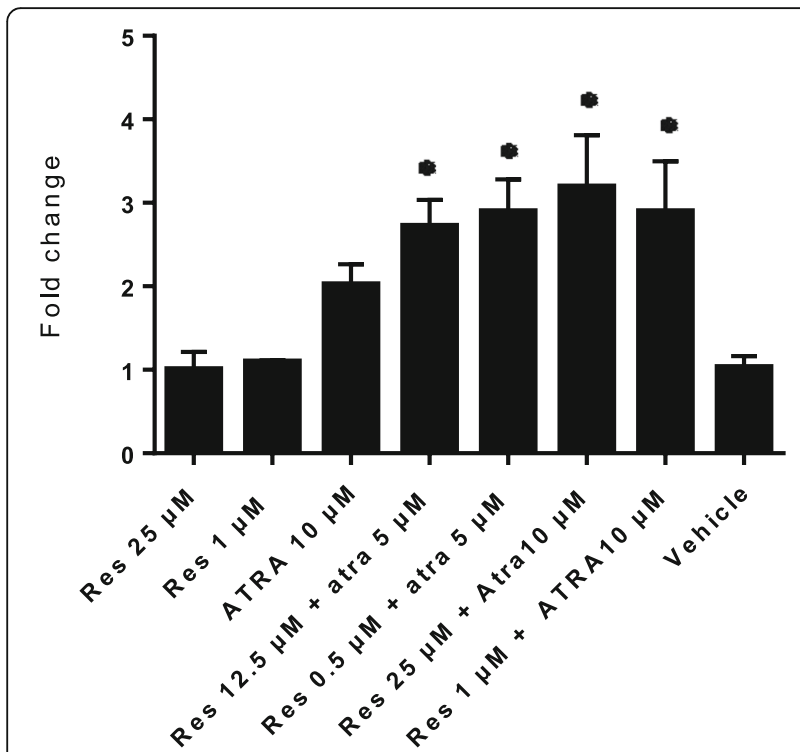

Fig. 2 The effects of single and combined treatment of ATRA and Res in different concentrations on the fold change of FNDC5 gene expression in $\mathrm{C} 2 \mathrm{C} 12$ cells after $12 \mathrm{~h}$ incubation

production. In spite of these findings, additional studies are necessary to determine if ATRA and Res would be as effective as the in vitro model presented here.

Empirical studies are usually performed in at least three independent expriments in triplicate tests. In the present study, two independent experiments were performed and all experiments were carried out in duplicate due to budget constraints. This limitation may explain the high variation of the data and achievement of a non-significant increase in FNDC5 gene expression in some experiment.

\section{Conclusion}

The result of this study has further elucidated the effects of single and combined treatment of ATRA and Res on the FNDC5 expression and metabolism of skeletal muscle adipocyte. In this study, the benefit of combination therapy was also evaluated. Taken together the nutrients supplement with the effect of thermogenesis have the potential to make a positive effect on obesity and the results of this study may reveal novel compounds in this line of investigation.

\section{Abbreviations \\ ANOVA: Analysis of variance; ATRA: All-trans retinoic acid; BAT: Brite/beige adipocyte; CAMP: Cyclic adenosine monophosphate; cDNA: Complementary DNA; CREB: CAMP response element binding protein; ERK: Extracellular Signal-regulated Kinase-1; FNDC5: Fibronectin type III domain containing-5; MAPK: Mitogen-activated protein kinase; PDE4: Phosphodiesterase4; PGC- 1a: Proliferator-activated receptor $\gamma$ coactivator-1a; PKA: Protein kinase $A$; PPAR: Peroxisome proliferator-activated receptor; Res: Resveratrol; SIRT1: Sirtuin 1; UCP-1: Uncoupling protein-1; WAT: White adipocyte}

\section{Acknowledgments}

This study was supported by a grant from Tehran University of Medical Sciences (92-02-161-23557). The contributions of the personnel who work in the Department of Cellular and Molecular Nutrition, School of Nutrition and Dietetics, Tehran University of Medical are sincerely appreciated.

\section{Authors' contributions}

EAT, ZV, ESM, LKH, SHJ, and AASY contributed equally to this work, were all involved in the design and draft,data collection and measurement, analysis and interpretation of the data and manuscript writing.. All authors read and approved the final manuscript.

\section{Funding}

The authors received no specific funding for this work.

Availability of data and materials

The datasets used and/or analyzed during the current study are available from the corresponding author on reasonable request.

Ethics approval and consent to participate

Not applicable.

Consent for publication

Not applicable.

\section{Competing interests}

The authors declare that they have no competing interests.

\section{Author details}

'Department of Cellular and Molecular Nutrition, School of Nutritional Sciences and Dietetics, Tehran University of Medical Sciences, Tehran, Iran. ${ }^{2}$ Department of Geriatric Medicine, Ziaeian Hospital, Tehran University of Medical Sciences, Tehran, Iran. ${ }^{3}$ Memory and Behavioral Neurology Division, Roozbeh Hospital, Tehran University of Medical Sciences, Tehran, Iran.

${ }^{4}$ Department of Cardiology, Ziaeian Hospital, Tehran University of Medical Sciences, Tehran, Iran. ${ }^{5}$ Health Management Research Center, Baqiyatallah University of Medical Sciences, Tehran, Iran. ${ }^{6}$ Department of Nutrition and Biochemistry, School of Public Health, Iran University of Medical Sciences, Tehran, Iran. ${ }^{7}$ Department of Immunology, School of Public Health, Tehran University of Medical Sciences, Tehran 141613151, Iran.

Received: 20 May 2019 Accepted: 3 October 2019

Published online: 22 October 2019

\section{References}

1. Pedersen BK, Febbraio MA. Muscles, exercise and obesity: skeletal muscle as a secretory organ. Nat Rev Endocrinol. 2012;8(8):457-65.

2. Vaughan R, Gannon N, Barberena M, Garcia-Smith R, Bisoffi M, Mermier C, et al. Characterization of the metabolic effects of irisin on skeletal muscle in vitro. Diabetes Obes Metab. 2014;16(8):711-8.

3. Huh J, Dincer F, Mesfum E, Mantzoros C. Irisin stimulates muscle growthrelated genes and regulates adipocyte differentiation and metabolism in humans. Int J Obes. 2014:38(12):1538.

4. Vaughan RA, Garcia-Smith R, Bisoffi M, Conn CA, Trujillo KA. Conjugated linoleic acid or omega 3 fatty acids increase mitochondrial biosynthesis and metabolism in skeletal muscle cells. Lipids Health Dis. 2012;11(1):142.

5. Sanchis-Gomar F. The skeletal muscle-metabolism Axis in prostate-cancer therapy. N Engl J Med. 2012;367(23):2257-8.

6. Raschke S, Eckel J. Adipo-myokines: two sides of the same coin-mediators of inflammation and mediators of exercise. Mediat Inflamm. 2013;2013:1-16.

7. Huh JY, Panagiotou G, Mougios V, Brinkoetter M, Vamvini MT, Schneider BE, et al. FNDC5 and irisin in humans: I. predictors of circulating concentrations in serum and plasma and II. mRNA expression and circulating concentrations in response to weight loss and exercise. Metabolism. 2012; 61(12):1725-38.

8. Moreno-Navarrete JM, Ortega F, Serrano M, Guerra E, Pardo G, Tinahones F, et al. Irisin is expressed and produced by human muscle and adipose tissue in association with obesity and insulin resistance. J Clin Endocrinol Metab. 2013;98(4):E769-E78.

9. Kuloglu T, Aydin S, Eren MN, Yilmaz M, Sahin I, Kalayci M, et al. Irisin: a potentially candidate marker for myocardial infarction. Peptides. 2014;55: 85-91.

10. Aronis KN, Moreno M, Polyzos SA, Moreno-Navarrete JM, Ricart W, Delgado $E$, et al. Circulating irisin levels and coronary heart disease: association with future acute coronary syndrome and major adverse cardiovascular events. Int J Obes(Lond). 2015;39(1):156-61. 
11. Young MF, Valaris S, Wrann CD. A role for FNDC5/Irisin in the beneficial effects of exercise on the brain and in neurodegenerative diseases. Prog Cardiovasc Dis. 2019;62(2):172-8.

12. Puigserver $P$, Spiegelman BM. Peroxisome proliferator-activated receptor- $\gamma$ coactivator 1a (PGC-1a): transcriptional coactivator and metabolic regulator. Endocr Rev. 2003;24(1):78-90.

13. Boström P, Wu J, Jedrychowski MP, Korde A, Ye L, Lo JC, et al. A PGC1-[agr]dependent myokine that drives brown-fat-like development of white fat and thermogenesis. Nature. 2012;481(7382):463-8.

14. Lo KA, Sun L. Turning WAT into BAT: a review on regulators controlling the browning of white adipocytes. Biosci Rep. 2013;33(5):e00065.

15. Kopelman PG. Obesity as a medical problem. Nature. 2000;404(6778):635

16. Marti A, Moreno-Aliaga M, Hebebrand J, Martinez J. Genes, lifestyles and obesity. Int J Obes. 2004;28(S3):S29.

17. Bilski J, Mazur-Bialy Al, Brzozowski B, Magierowski M, Jasnos K, Krzysiek Maczka G, et al. Moderate exercise training attenuates the severity of experimental rodent colitis: the importance of crosstalk between adipose tissue and skeletal muscles. Mediat Inflamm. 2015;2015.

18. Amengual J, García-Carrizo FJ, Arreguín A, Mušinović H, Granados N, Palou $A$, et al. Retinoic acid increases fatty acid oxidation and Irisin expression in skeletal muscle cells and impacts Irisin in vivo. Cell Physiol Biochem. 2018; 46(1):187-202.

19. Ahn J, Cho I, Kim S, Kwon D, Ha T. Dietary resveratrol alters lipid metabolism-related gene expression of mice on an atherogenic diet. J Hepatol. 2008;49(6):1019-28.

20. Cantó C, Gerhart-Hines Z, Feige JN, Lagouge M, Noriega L, Milne JC, et al. AMPK regulates energy expenditure by modulating NAD+ metabolism and SIRT1 activity. Nature. 2009;458(7241):1056.

21. Das S, Cordis GA, Maulik N, Das DK. Pharmacological preconditioning with resveratrol: role of CREB-dependent $\mathrm{BCl}-2$ signaling via adenosine a 3 receptor activation. Am J Phys Heart Circ Phys. 2005;288(1):H328-H35.

22. Park S-J, Ahmad F, Philp A, Baar K, Williams T, Luo H, et al. Resveratrol ameliorates aging-related metabolic phenotypes by inhibiting CAMP phosphodiesterases. Cell. 2012;148(3):421-33.

23. Morselli E, Maiuri M, Markaki M, Megalou E, Pasparaki A, Palikaras K, et al. Caloric restriction and resveratrol promote longevity through the Sirtuin-1dependent induction of autophagy. Cell Death Dis. 2010;1(1):e10.

24. Della-Morte D, Dave KR, DeFazio RA, Bao YC, Raval AP, Perez-Pinzon MA. Resveratrol pretreatment protects rat brain from cerebral ischemic damage via a sirtuin 1-uncoupling protein 2 pathway. Neuroscience. 2009;159(3): 993-1002.

25. Baur JA. Resveratrol, sirtuins, and the promise of a DR mimetic. Mech Ageing Dev. 2010;131(4):261-9.

26. Das S, Tosaki A, Bagchi D, Maulik N, Das DK. Potentiation of a survival signal in the ischemic heart by resveratrol through p38 mitogen-activated protein kinase/mitogen-and stress-activated protein kinase 1/cAMP response element-binding protein signaling. J Pharmacol Exp Ther. 2006;317(3):980-8.

27. Tan L, Yu J-T, Guan H-S. Resveratrol exerts pharmacological preconditioning by activating PGC-1a. Med Hypotheses. 2008;71(5):664-7.

28. Kim S-W, Hong JS, Ryu S-H, Chung W-C, Yoon J-H, Koo JS. Regulation of mucin gene expression by CREB via a nonclassical retinoic acid signaling pathway. Mol Cell Biol. 2007;27(19):6933-47.

29. Mercader J, Palou A, Bonet ML. Induction of uncoupling Protein-1 in mouse embryonic fibroblast-derived adipocytes by retinoic acid. Obesity. 2010; 18(4):655-62.

30. Lee MJ, Lee SA, Nam BY, Park S, Lee S-H, Ryu HJ, et al. Irisin, a novel myokine is an independent predictor for sarcopenia and carotid atherosclerosis in dialysis patients. Atherosclerosis. 2015;242(2):476-82.

31. Andrade JMO, Frade ACM, Guimarães JB, Freitas KM, Lopes MTP, Guimarães ALS, et al. Resveratrol increases brown adipose tissue thermogenesis markers by increasing SIRT1 and energy expenditure and decreasing fat accumulation in adipose tissue of mice fed a standard diet. Eur J Nutr. 2014; 53(7):1503-10.

32. Tourniaire F, Musinovic H, Gouranton E, Astier J, Marcotorchino J, Arreguin $A$, et al. All-trans retinoic acid induces oxidative phosphorylation and mitochondria biogenesis in adipocytes. J Lipid Res. 2015;56(6):1100-9.

33. de Ligt M, Timmers S, Schrauwen P. Resveratrol and obesity: can resveratrol relieve metabolic disturbances? Biochim Biophys Acta. 2015; 1852(6):1137-44.

34. Chang C-C, Lin K-Y, Peng K-Y, Day $Y-J$, Hung L-M. Resveratrol exerts antiobesity effects in high-fat diet obese mice and displays differential dosage effects on cytotoxicity, differentiation, and lipolysis in 3T3-L1 cells. Endocr J. 2016:63(2):169-78.

35. Noy $\mathrm{N}$. The one-two punch: retinoic acid suppresses obesity both by promoting energy expenditure and by inhibiting adipogenesis. Adipocyte. 2013;2(3):184-7.

36. Berry DC, DeSantis D, Soltanian H, Croniger CM, Noy N. Retinoic acid upregulates preadipocyte genes to block adipogenesis and suppress dietinduced obesity. Diabetes. 2012;61(5):1112-21.

37. Wolf $\mathrm{G}$. Retinoic acid activation of peroxisome proliferation-activated receptor $\delta$ represses obesity and insulin resistance. Nutr Rev. 2010;68(1):67-70.

38. Mirbolooki MR, Upadhyay SK, Constantinescu CC, Pan M-L, Mukherjee J. Adrenergic pathway activation enhances brown adipose tissue metabolism: a [18 F] FDG PET/CT study in mice. Nucl Med Biol. 2014;41(1):10-6.

39. Kim M, Lim J, Youn H, Hong Y, Yang K, Park H, et al. Resveratrol prevents renal lipotoxicity and inhibits mesangial cell glucotoxicity in a manner dependent on the AMPK-SIRT1-PGC1a axis in $\mathrm{db} / \mathrm{db}$ mice. Diabetologia. 2013;56(1):204-17.

40. Schirmer $H$, Pereira TCB, Rico EP, Rosemberg DB, Bonan CD, Bogo MR, et al. Modulatory effect of resveratrol on SIRT1, SIRT3, SIRT4, PGC1 $a$ and NAMPT gene expression profiles in wild-type adult zebrafish liver. Mol Biol Rep. 2012;39(3):3281-9.

41. Teruel T, Hernandez R, Benito M, Lorenzo M. Rosiglitazone and retinoic acid induce uncoupling protein-1 (UCP-1) in a p38 mitogen-activated protein kinase-dependent manner in fetal primary brown adipocytes. J Biol Chem. 2003;278(1):263-9.

42. Mahajan RD, Patra SK. Irisin, a novel myokine responsible for exercise induced browning of white adipose tissue. Indian J Clin Biochem. 2013; 28(1):102-3.

43. Viitasalo A, Ågren J, Venäläinen T, Pihlajamäki J, Jääskeläinen J, Korkmaz A, et al. Association of plasma fatty acid composition with plasma irisin levels in normal weight and overweight/obese children. Pediatr Obes. 2016;11(4): 299-305.

44. Farahabadi SH, Ghaedi K, Zadegan FG, Karbalaie K, Rabiee F, Nematollahi M, et al. ERK1/2 is a key regulator of Fndc5 and PGC1a expression during neural differentiation of mESCs. Neuroscience. 2015:297:252-61.

45. Cavalier É, Mismetti V, Souberbielle JC. Evaluation of circulating irisin levels in healthy young individuals after a single 100,000 IU vitamin D dose. Ann Endocrinol (Paris). 2014;75(3):162-4.

46. Seo DY, Kwak HB, Lee SR, Cho YS, Song I-S, Kim N, et al. Effects of aged garlic extract and endurance exercise on skeletal muscle FNDC-5 and circulating irisin in high-fat-diet rat models. Nutr Res Pract. 2014;8(2):177-82.

\section{Publisher's Note}

Springer Nature remains neutral with regard to jurisdictional claims in published maps and institutional affiliations.

Ready to submit your research? Choose BMC and benefit from

- fast, convenient online submission

- thorough peer review by experienced researchers in your field

- rapid publication on acceptance

- support for research data, including large and complex data types

- gold Open Access which fosters wider collaboration and increased citations

- maximum visibility for your research: over $100 \mathrm{M}$ website views per year

At $\mathrm{BMC}$, research is always in progress.

Learn more biomedcentral.com/submission 